Portland State University

PDXScholar

\title{
Making Sense of Human Ecology Mapping: An Overview of Approaches to Integrating Socio-Spatial Data into Environmental Planning
}

\author{
Rebecca J. McLain \\ Portland State University, mclainrj@pdx.edu \\ Melissa R. Poe \\ Northwest Sustainability Institute \\ Kelly Biedenweg \\ Puget Sound Institute \\ Lee Cerveny \\ US Forest Service Pacific Northwest Research Station \\ Diane Besser \\ Institute for Culture and Ecology

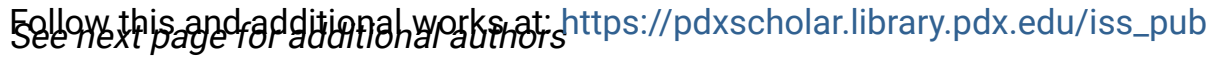 \\ Part of the Geographic Information Sciences Commons, and the Sustainability Commons \\ Let us know how access to this document benefits you.
}

\footnotetext{
Citation Details

McLain, R., Poe, M., Biedenweg, K., Cerveny, L., Besser, D., and Blahna, D. Making Sense of Human Ecology Mapping: An Overview of Approaches to Integrating Socio-Spatial Data into Environmental Planning. Hum Ecol (2013) 41: 651.
}

This Article is brought to you for free and open access. It has been accepted for inclusion in Institute for Sustainable Solutions Publications and Presentations by an authorized administrator of PDXScholar. Please contact us if we can make this document more accessible: pdxscholar@pdx.edu. 


\section{Authors}

Rebecca J. McLain, Melissa R. Poe, Kelly Biedenweg, Lee Cerveny, Diane Besser, and Dale Blahna 


\title{
Making Sense of Human Ecology Mapping: An Overview of Approaches to Integrating Socio-Spatial Data into Environmental Planning
}

\author{
Rebecca McLain • Melissa Poe • Kelly Biedenweg • \\ Lee Cerveny • Diane Besser • Dale Blahna
}

Published online: 24 February 2013

(C) Springer Science+Business Media New York (outside the USA) 2013

\begin{abstract}
Ecosystem-based planning and management have stimulated the need to gather sociocultural values and human uses of land in formats accessible to diverse planners and researchers. Human Ecology Mapping (HEM) approaches offer promising spatial data gathering and analytical tools, while also addressing important questions about human-landscape connections. This article reviews and compares the characteristics of three HEM approaches that are increasingly used in natural resource management contexts, each focused on a particular aspect of humanenvironmental interactions. These aspects include tenure and resource use (TRU), local ecological knowledge (LEK), and sense of place (SOP). We discuss their origins, provide examples of their use, and identify challenges to their application. Our review serves as a guide for environmental managers, planners, and communities interested in gathering spatial data on aspects of human ecology important in ecosystem-based management and planning, and for scientists designing socioecological research.
\end{abstract}

Keywords Human ecology mapping · Ecosystem-based planning $\cdot$ Socioecological systems $\cdot$ Landscape values mapping

\author{
R. McLain $(\bowtie) \cdot$ D. Besser \\ Institute for Culture and Ecology, Portland, OR, USA \\ e-mail: mclain@ifcae.org \\ M. Poe \\ Northwest Sustainability Institute, Seattle, WA, USA \\ K. Biedenweg \\ Puget Sound Institute, Tacoma, WA, USA \\ L. Cerveny $\cdot$ D. Blahna \\ USDA-Forest Service, Pacific Northwest Research Station, \\ Seattle, WA, USA
}

\section{Introduction}

Conservation scientists recognize the importance of integrating sociocultural data into ecosystem-based planning and management, as reflected in the use of terms such as socioecological systems (Alessa et al. 2008) and coupled humannatural systems (Liu et al. 2007). In practice, however, social and cultural dimensions are still only weakly incorporated into ecosystem-based analyses (St Martin and Hall-Arber 2008). Factors contributing to the limited use of sociocultural data include mismatches in the geographic and temporal scales of data collection between sociocultural and biophysical data, lack of connection between people and the landscapes, incompatible measurement systems, and lack of social science expertise in environmental management agencies and organizations (Endter-Wada et al. 1998; Endter-Wada and Blahna 2011). The growing reliance of land managers and environmental planners on geospatial techniques, including geographic information systems (GIS) and remote sensing tools, to study and manage ecosystems has created an additional barrier to the integration of sociocultural values into environmental planning. Numerous and detailed biophysical layers for GIS-based mapping and analysis are readily available, yet detailed socio-spatial layers data are limited.

Over the past two decades social scientists, community leaders, and indigenous groups have worked to address gaps in availability of socio-spatial data relevant to ecosystem-based planning and management. Much of this work is informed by citizens and stakeholder groups and falls within the fields of public participation, GIS, and participatory GIS. Community values mapping (Raymond et al. 2009), counter-mapping (Peluso 1995), cultural opportunities mapping (Tipa and Nelson 2008), landscape values mapping (Zhu et al. 2010), mental mapping (McKenna et al. 2008), participatory mapping (Herlihy 2003), place-based planning (Farnum and Kruger 
2008), public participation GIS (Brown and Reed 2009), and social values mapping (Sherrouse et al. 2011) are some of the terms used to describe these projects. All of these efforts seek to map the diverse and complex connections between humans and landscapes and thus fit under the broad umbrella of what we refer to as human ecology mapping (HEM).

Human ecology is a transdisciplinary science that focuses on understanding human-environmental interactions by "tracing chains of effects through ecosystems and human society" (Marten 2001: xv) with the goal of anticipating long-range environmental effects of human activities. It seeks to understand the world as a series of interrelated complex and dynamic systems operating at multiple scales (Steiner 2002). Maps are useful tools for identifying and visualizing humanenvironmental connections that have a spatial component and which are often difficult to discern using non-spatial analytical techniques. Recent technological advances in computerized mapping and visualization tools, including GIS, interactive web technologies, GPS receivers, and smartphones, together with the increasing availability of relatively low-cost remote sensing products, have created opportunities to visualize and explore human-environment connections that were previously invisible. Human ecology mapping uses these emerging technologies, as well as older ones, to capture the complex and dynamic interactions that characterize socioecological systems.

Although maps are important means of communication, they are never objective abstractions of reality (Soini 2001). What is included —or excluded - from a map, reflects and reinforces the values and beliefs of the society in which the mapmaker is embedded (Rundstrom 1990). Moreover, the inclusions and exclusions have the power to affect who controls the use of space (Harley 1988), who has access to environmental resources (Peluso 1995), whose ecological knowledge is considered legitimate (Rundstrom 1990), and whose values and interests influence natural resource decisions (Bethel et al. 2011).

More recently, geographers have begun to see maps as performance, and imbued with power relations (Perkins 2003). Understanding the performative qualities of maps shifts attention from the maps and debates about what they represent, to the process of map-making and explorations of how "a map becomes part of a story, to be created and enacted, rather than simply serving as a discourse for the powerful" (Perkins 2003:345). The interpretive qualities of maps make human ecology mapping a particularly useful tool for understanding how individuals or groups view the world and for comparing how landscape meanings of local people differ from landscape valuations by scientists (Soini 2001). At the same time, the performance qualities of mapmaking make HEM approaches, with their emphasis on providing venues where views about human-environmental interactions can be explored in contexts governed by principles of openness and mutual respect, potential empowerment tools (Sletto 2009).
Choosing among human ecology mapping approaches is no easy task. The scholarly literature on HEM is scattered across numerous disciplines and sub-disciplines, including cultural ecology, human ecology, political ecology, human geography, anthropology, environmental psychology, natural resource sociology, urban planning, and community development. Sorting through the strengths and limitations of different approaches to HEM is daunting when one considers the variety of methods used to collect and represent sociocultural data spatially, as well as the diversity of resource management themes explored and sociocultural variables measured.

This article is a guide for environmental managers, planners, researchers, and local communities interested in gathering spatial data on aspects of human ecology important in ecosystembased management and planning. We examine three approaches to HEM: tenure and resource use (TRU); local ecological knowledge (LEK); and sense of place (SOP) mapping. Each approach addresses distinct questions about human-landscape connections that may arise in environmental planning. In real world mapping contexts these themes often overlap and mapping projects may address a combination of themes.

- Tenure and resource use mapping (TRU) delineates the spatial locations of land and resource tenure and land uses that connect humans to a landscape or particular landscape features.

Questions that TRU mapping typically addresses include: What ownership, use, and access rights to land and other resources exist in the area being managed? Who exerts those claims and what activities are associated with them? Where do conflicts over ownership, use, and access rights exist?

- Local ecological knowledge mapping (LEK) aims to capture local groups' understandings of ecological processes and relationships between humans and their environment. Traditional ecological knowledge and indigenous ecological knowledge mapping are variants of LEK mapping. LEK mapping seeks to answer questions such as: How are human activities on the land or sea related to the ecological conditions present in the management area? How and why does the spatial distribution of human activities vary seasonally, annually, and over the long-term?

- Sense of place mapping (SOP) seeks to describe the values and/or meanings that people ascribe to landscapes, particular locations on landscapes, and activities associated with those landscapes. Questions that drive SOP mapping include: What values and meanings are associated with different areas of the landscape(s) being managed? How do these values and meanings differ across cultural and socio-demographic categories, such as ethnicity, race, age, gender, and class or among various cultural groups, tribes, user groups, landowners, or stakeholders? Where do landscape values and meanings conflict with each other or with proposed land management actions? 
For each approach, we briefly describe its origins, data collection and analysis methods and processes, major applications, and associated challenges. We discuss key differences among the approaches and conclude by summarizing cross-cutting challenges, such as the limitations of GIS as a tool for HEM, power dynamics, and manager resistance to the use of HEM data. Citations are provided for readers interested in delving more deeply into theoretical underpinnings and applications.

\section{Tenure and Resource Use Mapping}

The basic premise of tenure and resource use (TRU) mapping is that politically and economically marginalized groups can assert or strengthen existing claims over lands and resources through the production of maps that represent their conceptions of their territories rather than the boundaries that have been imposed on them by nation-states or other outside entities (Fox 2002; Peluso 1995; Tobias 2000). We consider a variety of mapping approaches under the rubric of TRU mapping, including land use and land occupancy, counter-mapping, indigenous mapping, and community-based natural resource management mapping. We also include participatory GIS (PGIS) efforts that focus on the mapping of resource tenure claims and use patterns.

Tenure and resource use (TRU) mapping is strongly rooted in the cultural ecology, political ecology, and international development subfields of cultural anthropology and human geography. It is also heavily informed by participatory action and research theory and methods (Herlihy 2003). The theory underlying TRU mapping posits that local populations have detailed knowledge of their surrounding lands and resources, knowledge that is often embedded in place names, stories, songs, and artwork. Mapping is viewed as a social and political practice, not just a technical one (Fox 2002; Peluso 1995). Consequently, mapping processes that are collaborative, attend to internal and external power dynamics, and minimize opportunities for powerful individuals, groups, or communities to dominate mapping are heavily emphasized (Herlihy 2003).

TRU mapping has two identifiable origins (Chapin et al. 2005) - use and occupancy mapping projects in Canada and Alaska during the 1960s and 1970s and Participatory Rural Appraisal (PRA)/Participatory Action Research (PAR) projects in Latin America, Asia and Africa during the 1980s and early 1990s. Hugh Brody's Maps and Dreams (1982) is a seminal work in the field of TRU mapping, describing an effort in which indigenous groups, government bureaucrats and representatives of energy companies in northern British Columbia developed plans for energy development that would protect local settlements and their access to subsistence resources. Maps of the spaces and places of land use and occupancy for the Beaver People provided critical data for these plans, including spatial references to the Beaver
People's histories of belonging, community formation, and gathering, hunting and fishing practices.

Regardless of origins, a fundamental characteristic of TRU mapping projects is direct participation in the mapping process of individuals embedded in the landscapes being mapped (Chapin et al. 2005). Maps produced through this process have the potential to fundamentally alter power dynamics between government agencies and society (Chapin et al. 2005; Peluso 1995). They can also alter dynamics within communities. In the Bolivian Amazon, for example, mapping was employed to clarify locallydefined tenure boundaries and internal access rights to individual Brazil nut trees (Cronkleton et al. 2010). Members of the forest community formed census brigades to map each Brazil nut tree within the community's boundaries. When a conflict over access rights arose, the conflict was mediated by others in the brigade and mapping continued until most trees had been identified and allocated to individual families for harvesting rights. As a result of this process, the community was able to negotiate land boundaries with the land granting agency that had excluded a portion of their traditional area in newly created property maps.

\section{TRU Mapping Methods and Processes}

In a guide created for Canadian indigenous communities, Terry Tobias (2000) lays out the essentials of TRU mapping with local people. While methods vary among communities, the ideal method includes generating community consensus about the project, collaboratively developing a research design with a trained professional and the local community, gathering and analyzing data, validating maps with the community, and writing a report. The first step, obtaining community support, is probably the most often overlooked, yet it is crucial to project success. Data collection methods usually include key informant or focus group interviews; participants marking locations on paper maps, aerial photos, or satellite images; and gathering or verifying points and boundaries in the field with GPS technology (see, e.g., Bauer 2009; Sletto 2009; Smith et al. 2012). Individual maps are combined to produce community maps, which are then validated through workshops or focus groups. The stories that go with the maps are considered as important as spatial locations, as they reveal the social relationships that underlie particular socioecological systems (Sletto 2009; Vermeylen and Davies 2012).

TRU mapping protocols are often developed collaboratively and many projects are structured to build long-term local mapping capacity through the training of community members as ethnocartographers (Herlihy 2003). New technologies, such as CyberTracker, a customized GPS and software unit that can be programmed with icons and other visual prompts, have expanded local capacity to collect 
tenure and resource use data in Mexico (Smith et al. 2012), South Africa (Barodien and Barry 2004) and the Congo rainforest (Lewis 2012). As they become more widely used, smartphones and tablet computers hold promise as easy-touse tools for on-the-spot collecting, recording, and mapping of geospatial TRU data (McCall and Dunn 2012). An additional step in tenure mapping is the presentation of results to external parties, such as governments or non-local landowners, for formalizing claims or mediating conflict about land boundaries (Mather 2000; McCall and Minang 2005).

The spatial analysis and representation of TRU mapping is often quite simple. It requires delineating points and lines that were recorded in the field. Attributes such as colors or symbols can be applied to differentiate data specific to a type of resource or ownership group (e.g.,family). In the Bolivian example above, access trails were drawn as lines and individual trees were marked as points (Cronkleton et al. 2010). Each point was assigned a color corresponding to the family that had access to its nuts, producing a multicolored map representing regions of use rights.

\section{Applications of TRU Mapping}

TRU mapping has been used for many purposes including resolving internal community conflicts over resources (Kyem 2004), formalizing traditionally recognized land boundaries (Hodgson and Schroeder 2002), empowering communities to assert and defend land or resource rights (Herlihy 2003; Peluso 1995), and assessing the impacts of policy reforms on tenure systems (Smith et al. 2012). TRU mapping has also proved useful for establishing comanagement agreements (McCall and Minang 2005) and land use plans (McCarthy et al. 2012). Enhancing intergenerational knowledge exchange is an important goal of some projects (Lewis 2012; Sletto 2009). Other applications include establishing relationships of trust within or between communities (Kyem 2004), improving relationships between communities and external agencies (Mather 2000), and enhancing livelihood opportunities for rural community members (Chapin et al. 2005).

\section{Challenges Associated with TRU Mapping}

Chapin et al. (2005) observe that outside "technical experts" typically take on central roles in most TRU mapping initiatives due to a variety of factors, including lack of technical capacity within local communities and the different timelines of technical experts versus community members. While outside assistance can be advantageous - and in some cases necessary - it carries with it the risk that outsiders will control what data is collected and how it is used (Fox 2002).

TRU mapping processes favor those who show up to map; educational, social status, and wealth differentials may inhibit participation by particular sub-groups, age cohorts, and oftentimes women (McCall and Minang 2005). The absence of key groups can result in data on resource conditions remaining unrecorded (Mather 2000) or in absent groups losing access to resources that are critical for their livelihoods (Lewis 2012). A related issue is that more highly educated or more powerful factions may seek to dominate the mapping process as a means for acquiring control over land or resources. Barnaud et al. (2010) found that in Thailand's highlands, scenario modeling workshops with careful selection of participants was an effective approach to creating opportunities for less powerful community members to have a voice in resource management discussions.

Finally, it is important to consider the possible consequences of developing tenure and resource use maps. The use of western cartographic conventions risks establishing fixed boundaries in areas where boundaries have traditionally been porous and communities interdependent, provoking conflicts as some claims are extinguished in favor of others (Bryan 2011) and reducing the ability of communities to adapt to shifting ecological conditions (Hodgson and Schroeder 2002; Vermeylen and Davies 2012). The process of defining boundaries and formalizing land claims also may prompt village leaders to sell titled communal land which would have been difficult to sell when the land was held under informal tenure arrangements (Hodgson and Schroeder 2002). Structuring TRU mapping projects so that secondary and overlapping rights are identified and recognized is one means by which the risks associated with mapping can be reduced (Bryan 2011). Building in precautions against corrupt village leaders requires acknowledging that corruption may exist and integrating legal and political strategies, such as legal education and linking community members to external organizations actively promoting transparency in resource governance (Hodgson and Schroeder 2002).

\section{Local Ecological Knowledge Mapping}

The movement to assert territorial claims through TRU mapping has been accompanied by parallel, and often linked, efforts to map local ecological knowledge (LEK) in formats compatible with Cartesian cartography, a process we refer to here as LEK mapping. Charnley et al. (2008:2) define LEK as "knowledge, practices, and beliefs regarding ecological relationships that are gained through extensive personal observation of and interaction with local ecosystems, and shared among local resource users." Terms related to LEK include traditional ecological knowledge (TEK), which is generally considered to have developed over a much longer time than local ecological knowledge (Berkes 
et al. 2000), and indigenous ecological knowledge (IEK), TEK that is specific to indigenous peoples (Aswani and Lauer 2006). Theory and empirical research on LEK draw heavily from the disciplines of cultural anthropology and human geography, particularly the subfields of cultural ecology, ethnobotany, ethnobiology, and cognitive anthropology.

Spatialized knowledge consists of several elements: memorizing places in relation to an event (landmark knowledge), developing a sense of the sequence in which places occur (path or route knowledge), and understanding how multiple places relate to each other in ways that permit creative navigation (survey knowledge) (Ishikawa and Montello 2006). Resource users develop spatialized LEK primarily by direct environmental interactions, often in an apprenticeship-type relationship with more experienced people, but also through listening to stories (or more recently through reading or watching movies, television, or videos) shared by other individuals or groups (Aswani and Lauer 2006; Feinberg et al. 2003). Through environmental and cultural interactions, resource users develop cognitive maps - internal representations of the world and its spatial properties - that allow them to know what features exist in the world, what the attributes of those features are, where they are located, and how to get to them. Over time, resource users can develop a collective body of knowledge about the environment that extends back through time and across relatively large spaces (McKenna et al. 2008; Hall et al. 2009a). The main purpose of LEK historically was to enable resource users to survive (Berkes et al. 2000).

Like all knowledge, LEK is embedded in the practices, management institutions, and world view of its knowledge community participants (Berkes et al. 2000). Consequently, integrating LEK with scientific knowledge requires looking beyond the collection of factual LEK and identifying ways in which the world views and management institutions of LEK holders can be incorporated into environmental planning (Houde 2007). Rather than viewing LEK and scientific knowledge as in opposition, many scholars argue that it is more productive to view them as knowledge-belief-value systems that, while providing different facts and based on different world views, are potentially complementary (Agrawal 1995; Houde 2007). Hybrid knowledge systems in which LEK incorporates scientific facts and data collection technologies (Kendrick and Manseau 2008; Murray et al. 2008), and ecological research incorporates LEK, are becoming increasingly common (Bethel et al. 2011; Gilchrist et al. 2005; Hall et al. 2009a).

\section{LEK Mapping Methods and Processes}

LEK mapping uses a mix of qualitative and quantitative methods (Table 1). Key informant or focus group interviews are typically used to collect data about place names, cultural meanings, uses, and changing conditions of important locations. Interviewees identify the locations of key places using sketch maps, aerial photos, or satellite images. Most LEK mapping projects incorporate field visits to collect GPS points and other data about mapped locations. Once the data have been compiled into map form, the maps are validated in workshops or focus groups. GPS technology is sometimes customized so that resource users can record data when scientists are not present. For example, Canadian university students worked with Inuit hunters in the Arctic to co-design Igliniit, a GPS unit and software interface that hunters use to mark waypoints as they travel, and log observations of animals, ice features, hazardous areas, and other data as part of their everyday activities (Gearheard et al. 2011). In areas where internet access is relatively common, such as the North American Arctic, researchers are experimenting with creating interactive multi-media webbased atlases and databases where local ecological knowledge can be shared and updated (Eisner et al. 2012; Pulsifer et al. 2011). Contextual data such as videos, photos, narratives by LEK holders, and copies of historic documents are increasingly being included in LEK geodatabases (Aporta 2011; Hall et al. 2009a).

The final step of LEK mapping is to combine or compare LEK data with scientific data for use in environmental planning or management. For example, in the Solomon Islands, Aswani and Lauer (2006) combined 7 years of fishermen's data with data collected by natural and physical scientists. From 300 interviews with local inhabitants, they created a substantial LEK database about the spatial and temporal characteristics of fishing grounds and benthic habitats. Once processed and overlaid with biophysical data, these records provided important information for predicting fishing behavior and determining the boundaries of marine protected areas. Roth (2004) argues that successful integration of LEK and scientific knowledge requires more than agreement on facts; it also requires that local and scientific ecological knowledge communities reach agreement on how resources should be managed.

\section{Applications of Local Ecological Knowledge Mapping}

Efforts to map LEK for natural resource management began on a large-scale in the 1970s and 1980s among indigenous peoples in Alaska and Canada. LEK mapping was seen as a tool to challenge scientific data used to justify wildlife harvest restrictions, data which indigenous peoples' experiences suggested rested on inaccurate assumptions about wildlife migration patterns and therefore greatly underestimated extant populations of economically important species (Freeman 1992). Building on this foundation, many LEK mapping projects explicitly seek to empower resource users or local communities by providing an avenue for their 
Table 1 Comparison of human ecology mapping approaches

\begin{tabular}{|c|c|c|c|}
\hline & Tenure and resource use (TRU) & Local ecological knowledge (LEK) & Sense of place (SOP) \\
\hline $\begin{array}{l}\text { Participation } \\
\text { model }\end{array}$ & Empowerment & Empowerment/co-creation of knowledge & $\begin{array}{l}\text { Variable: Mostly contributory but some } \\
\text { studies are collaborative and others } \\
\text { involve co-creation of planning } \\
\text { knowledge or political empowerment }\end{array}$ \\
\hline \multirow[t]{4}{*}{$\begin{array}{l}\text { Major } \\
\text { applica- } \\
\text { tions }\end{array}$} & $\begin{array}{l}\text { Advancement of claims for land and } \\
\text { resources previously appropriated by } \\
\text { nation-states }\end{array}$ & $\begin{array}{l}\text { Integration with scientific data to } \\
\text { produce predictive models (i.e., } \\
\text { impacts of climate change on habitats) }\end{array}$ & $\begin{array}{l}\text { Identification of areas where values or } \\
\text { place meanings conflict or mesh with } \\
\text { proposed natural resource management } \\
\text { actions }\end{array}$ \\
\hline & $\begin{array}{l}\text { Land and resource conflict resolution } \\
\text { and mitigation }\end{array}$ & $\begin{array}{l}\text { Integration with scientific data to select } \\
\text { locations for marine protected areas }\end{array}$ & $\begin{array}{l}\text { Identification of areas where values or } \\
\text { place meanings conflict with each other }\end{array}$ \\
\hline & $\begin{array}{l}\text { Development of community } \\
\text { management plans }\end{array}$ & $\begin{array}{l}\text { Development of community } \\
\text { management plans }\end{array}$ & $\begin{array}{l}\text { Building relationships of trust } \\
\text { (collaborative mapping) }\end{array}$ \\
\hline & $\begin{array}{l}\text { Building relationships of trust between } \\
\text { communities and external groups }\end{array}$ & $\begin{array}{l}\text { Building relationships of trust between } \\
\text { communities, scientists, and resource } \\
\text { management agencies }\end{array}$ & $\begin{array}{l}\text { Improved understanding of the } \\
\text { combination of environmental and } \\
\text { social factors that provide a "feeling" } \\
\text { of wilderness }\end{array}$ \\
\hline \multirow{12}{*}{$\begin{array}{l}\text { Primary } \\
\text { data } \\
\text { collection } \\
\text { methods }\end{array}$} & Wide range of methods & Wide range of methods & Values mapping \\
\hline & - Focus groups & - Focus groups & - Surveys \\
\hline & - Semi-structured interviews & - Semi-structured interviews & Place attachment \\
\hline & - Oral histories & - Oral histories & - Semi-structured interviews \\
\hline & - Land management histories & - Land management histories & - Focus groups for feedback \\
\hline & - Transect walks & - Transect walks & Wilderness perceptions mapping \\
\hline & - Surveys & - Surveys & - Surveys \\
\hline & - Map biographies & - Map biographies & Collaborative mapping \\
\hline & - Photo narratives & - Photo narratives & $\begin{array}{l}\text { - Workshops or focus groups to develop } \\
\text { consensual maps; }\end{array}$ \\
\hline & - Trip diaries & - Trip diaries & - Key informant interviews \\
\hline & - Grounded diaries & - Grounded diaries & Hybrids \\
\hline & & & - Mixed methods \\
\hline \multirow[t]{6}{*}{$\begin{array}{l}\text { Major } \\
\text { challenges }\end{array}$} & $\begin{array}{l}\text { Mapping boundaries can have the } \\
\text { unintended consequence of turning } \\
\text { fluid boundaries into rigid boundaries, } \\
\text { reducing the capacity of communities } \\
\text { to adapt to socioecological changes. }\end{array}$ & $\begin{array}{l}\text { Essential qualitative details, such as } \\
\text { cultural meanings and histories, are not } \\
\text { easily captured in LEK mapping, } \\
\text { resulting in maps that are only partial } \\
\text { representations of LEK. }\end{array}$ & $\begin{array}{l}\text { Most SOP mapping does not include a } \\
\text { ground-truthing component making } \\
\text { SOP maps highly susceptible to } \\
\text { locational errors and ambiguities in } \\
\text { spatial representations. }\end{array}$ \\
\hline & \multirow{5}{*}{$\begin{array}{l}\text { Communities are heterogenous and more } \\
\text { powerful members may seek to } \\
\text { dominate the mapping process, } \\
\text { depriving less powerful community } \\
\text { members of access to resources. } \\
\text { Communities often lack capacity to map } \\
\text { and analyze mapped data with the } \\
\text { result that outsiders may end up } \\
\text { controlling the process. This may lead } \\
\text { to misrepresentations of boundaries or } \\
\text { conflicts and undermines } \\
\text { empowerment goals. } \\
\text { The process of defining boundaries can } \\
\text { spark latent claims to resources leading } \\
\text { to conflicts where previously there } \\
\text { were none. }\end{array}$} & $\begin{array}{l}\text { Managers are often skeptical of the } \\
\text { validity of LEK data and resist } \\
\text { incorporating it into planning. }\end{array}$ & $\begin{array}{l}\text { Boundaries of values and special places } \\
\text { are fuzzy and challenging to depict in } \\
\text { hand-drawn or computerized maps. }\end{array}$ \\
\hline & & \multirow{4}{*}{$\begin{array}{l}\text { Communities often lack capacity to } \\
\text { implement LEK mapping and outsiders } \\
\text { may control the process. This may lead } \\
\text { to misinterpretation or misuse of LEK } \\
\text { data and undermines empowerment } \\
\text { goals. } \\
\text { LEK mapping projects typically have not } \\
\text { included provisions for long-term data } \\
\text { storage, maintenance, and updating. As } \\
\text { a result, data from LEK mapping done } \\
\text { several years ago may not reflect } \\
\text { changes in socioecological conditions } \\
\text { or understandings of the environment. }\end{array}$} & $\begin{array}{l}\text { Certain subgroups are less likely to } \\
\text { participate in surveys, interviews, and } \\
\text { focus groups, resulting in a gap in the } \\
\text { range of values, perceptions, or place } \\
\text { attachments collected. }\end{array}$ \\
\hline & & & \multirow{2}{*}{$\begin{array}{l}\text { Managers have tended to be resistant to } \\
\text { using data from values mapping } \\
\text { projects; they have been more open to } \\
\text { incorporating data from place } \\
\text { attachment projects. }\end{array}$} \\
\hline & & & \\
\hline & & & $\begin{array}{l}\text { The qualitative data generated by place } \\
\text { attachment mapping and some hybrid } \\
\text { SOP mapping projects is challenging to } \\
\text { integrate into GIS databases and } \\
\text { analyses. }\end{array}$ \\
\hline
\end{tabular}


knowledge and perspectives to enter externally-driven environmental planning and management processes (Bethel et al. 2011; Murray et al. 2008). LEK mapping is an important tool for gathering data that are difficult to collect using scientific procedures, but for which detailed LEK is already available. For example, Inuit hunters participating in the Igliniit project described earlier are able to record data on environmental conditions for a much larger area and more continuously than is feasible with standard meteorological and biological monitoring approaches (Gearheard et al. 2011). Historical management data from LEK can be used to formulate and test hypotheses about how people will react to ecological variability and future resource management decisions (Aswani and Lauer 2006; St. Martin and HallArber 2008). LEK mapping can also highlight high use areas and provide a venue for identifying and mitigating conflict in those areas (de Freitas and Tagliani 2009).

LEK mapping has been applied to marine spatial planning in New England (St. Martin and Hall-Arber 2008), Canada (Murray et al. 2008), Brazil (de Freitas and Tagliani 2009), New Zealand (Hall et al. 2009a), and the Solomon Islands (Aswani and Lauer 2006), among other countries. It is used in Canada for understanding topics as diverse as changes in polar sea ice conditions (Aporta 2011), caribou migration patterns (Kendrick and Manseau 2008), and migratory bird population dynamics (Gilchrist et al. 2005). LEK also has been combined with scientific data to develop better understandings of the drivers of land cover change on South Africa's Wild Coast (Chalmers and Fabricus 2007) and of livelihood vulnerability and marsh habitat sustainability assessments for coastal communities in Louisiana (Bethel et al. 2011).

\section{Challenges Associated with Local Ecological Knowledge Mapping}

A major challenge associated with mapping LEK for environmental planning is that essential qualitative details, such as cultural meanings, resource health, and changes in species distribution over time, may get lost in the process of translating LEK into western cartographic maps (Kendrick and Manseau 2008). While advances have been made in linking qualitative LEK data into geodatabases, researchers are still struggling to develop effective ways of integrating it into GIS-based maps for resource management (de Freitas and Tagliani 2009).

Another barrier to the widespread use of LEK in environmental planning and management is resource managers' skepticism about the validity of LEK (Hall et al. 2009a, b; Roth 2004). Systematic research that helps resource managers better understand the strengths and limitations of both LEK and scientific knowledge may be one avenue by which resistance to LEK can be overcome (Chalmers and Fabricius
2007; Hall et al. 2009a, b). Working toward resource management systems that rely on the co-production of knowledge and that engage LEK holders early on in planning processes has also been suggested as a means to alleviate manager concerns about the validity of LEK (Houde 2007). Palmer and Wadley (2007) argue that some questions about LEK validity can be addressed by research that focuses on studying LEK through observing lived practices rather than relying for evidence on LEK holders' talk about environmental knowledge.

The issue of control over knowledge-including who should have control over LEK mapping processes and products - is another challenge, particularly if local empowerment is an objective. Historically, outside experts have dominated many LEK projects, raising concerns within local knowledge communities about whether community members risk losing control over what data is collected, how it is collected, and how it is shared.

Finally, most LEK mapping projects have no provision for updating maps and datasets as socioecological conditions and resource users' understandings of their environment change (Houde 2007). As the use of technologies that permit the collection of large amounts of data on an ongoing basis expands, there is new urgency to ensure that provisions are made for the processing, storage, retrieval, and updating of extremely large data sets (Pulsifer et al. 2011). This is particularly important if LEK is to be integrated into long-term and large-scale environmental monitoring programs.

\section{Sense of Place Mapping}

SOP mapping draws on theory and empirical research in behavioral geography and environmental psychology regarding the concept of sense of place and the relationship between sense of place and cognitive maps. Williams and Stewart (1998:21) describe sense of place as "the idea that places have meaning to people". SOP theorists argue that humans form attachments and assign meanings to places based on a variety of experiences (real or imagined) that occur in a particular place, such that "what begins as undifferentiated space becomes place as we get to know it better and endow it with value" (Tuan 1977:6). Place meanings are intertwined with placeidentity and involve a combination of beliefs, memories, and values (Proshansky et al. 1983); such meanings can emerge from direct personal experiences with particular places, through listening to others' experiences, or through reading or watching movies about places one has never visited. Additionally, physical attributes of settings influence the meanings that people assign to them (Stedman 2003). 
Understanding sense of place is important to environmental planners because the meanings people attach to landscapes influence how they respond to proposed management actions (Stedman 2003). For example, removing underbrush in forests to reduce the risk of fire may induce negative reactions from individuals who prefer forests to have a "wild" feeling but positive reactions from those who prefer park-like settings. The emotional attachments people have to landscapes can motivate stewardship activities (Stedman 2003); differences in the meanings different groups attach to places lie at the heart of many environmental conflicts (Cheng et al. 2003).

Behavioral geographers began using maps to explore sense of place in the 1960s. Lynch (1960) demonstrated that city residents' free-hand sketch maps of their city showed a high degree of consistency in areas identified as meaningful or lacking distinctiveness. He argued that such sketch maps were physical representations of study participants' "mental maps", and that understanding those images could help planners better predict how proposed design changes would affect those images. A decade later, Gould (1970) showed that individual mental maps could be aggregated to identify regional differences in residential preferences by using a common base map as a template rather than relying on free-hand sketches. Mental mapping has since been widely used in urban and residential planning (Soini 2001), but only in the past decade has it been widely applied in rural contexts.

\section{SOP Mapping Methods and Processes}

Terms used to describe SOP mapping include community values mapping (Raymond et al. 2009), landscape values mapping (Carver et al. 2009), social values mapping (Sherrouse et al. 2011), place mapping (Cacciapaglia et al. 2012), place-based planning (Farnum and Kruger 2008), and wilderness perceptions mapping (Kliskey and Kearsley 1993) among others. In the sense of place mapping literature we identified four fairly distinct strands differing according to what they map, data collection and analysis methods, and participation models (Table 2). The distinctions between these approaches are not clear cut; a number of researchers have used hybrid approaches (see, e.g., Carver et al. 2009; Fagerholm et al. 2012; Fagerholm and Käyhkö 2009; Klain and Chan 2012; McIntyre et al. 2008).

Values Mapping This strand of SOP mapping draws on a conceptual and methodological framework developed by Brown et al. (2002) for use in national forest planning. They collected sense of place data using quantitative methods likely to be familiar to land managers with training in the natural sciences with the hope that managers would be more likely to use the data. Their framework measures the location and intensity of values participants associate with particular landscapes or features of landscapes.

Values mapping projects begin by creating a values typology that participants use to assign values to different parts of the landscape. Providing a pre-defined set of values reduces coding time and, if the same typology is used for different studies, permits cross-study comparisons. Examples of values included in typologies include: aesthetic, biological, cultural, economic, future, historic, intrinsic, learning, life sustaining, recreation, spiritual, subsistence, therapeutic, and wilderness.

Mail or internet surveys are typically used to collect data. Survey respondents map locations they consider important and assign values to those locations using the typology. Maps displaying the relative density of values across the landscape are produced for each value and spatial relationships between landscape values and roads, water bodies, settlements or other relevant features are described (see Beverly et al. 2008; Sherrouse et al. 2011). Participants in most values mapping studies are typically treated as data contributors and have minimal input in research design, implementation, or data analysis and interpretation.

Place Attachment Mapping This variant of SOP mapping seeks to elicit detailed information about the emotional attachments or meanings associated with places. Gunderson and Watson (2007) argued that the values mapping methodology developed by Brown et al. is ill-suited to describing the complexity of interactions between emotions, values, experiences, and beliefs that form and influence attachments to place. Place attachment mapping researchers (Table 2) typically collect data through open or semistructured interviews during which participants map locations they consider important, as well as giving the reasons why those places are important. Qualitative analysis software is used to identify key themes and values associated with the mapped locations. GIS layers for the themes and values are developed and maps are produced showing the distribution of aggregated values and their relationship to biophysical features. Place attachment practitioners contend that developing the values categories inductively from interview data allows researchers to better capture respondents' place meanings (Cacciapaglia et al. 2012; Gunderson and Watson 2007). However, transcribing and coding interviews is time-consuming. In addition to soliciting data from participants, place attachment studies often build in feedback opportunities during the data analysis process.

Wilderness Perceptions Mapping This strand of SOP mapping uses GIS overlays to model the spatial distribution of public perceptions about wilderness (see Table 2). It seeks to answer the question of "whose wilderness is where" (Kliskey and Kearsley 1993:206). Surveys are used to 
Table 2 Comparison of sense of place mapping approaches

\begin{tabular}{|c|c|c|c|c|}
\hline $\begin{array}{l}\text { Sense of } \\
\text { place } \\
\text { mapping } \\
\text { category }\end{array}$ & $\begin{array}{l}\text { Sense of place dimensions } \\
\text { mapped }\end{array}$ & Dominant methods & $\begin{array}{l}\text { Participation model (Categories } \\
\text { adapted from Bonney et al. 2009) }\end{array}$ & $\begin{array}{l}\text { Examples } \\
\text { (Chronological } \\
\text { order) }\end{array}$ \\
\hline \multirow[t]{7}{*}{$\begin{array}{l}\text { Values } \\
\text { mapping }\end{array}$} & \multirow[t]{7}{*}{$\begin{array}{l}\text { Values (most include a } \\
\text { weighting scheme) }\end{array}$} & Mail or internet surveys & \multirow{7}{*}{$\begin{array}{l}\text { Contributory - Public provides data; } \\
\text { Alessa et al. mention post-mapping } \\
\text { focus group discussions but } \\
\text { provide no details on the purpose or } \\
\text { nature of those discussions }\end{array}$} & $\begin{array}{l}\text { Brown et al. } \\
2002\end{array}$ \\
\hline & & Random sampling selection strategy & & $\begin{array}{l}\text { Tyrväinen et } \\
\text { al. } 2007\end{array}$ \\
\hline & & $\begin{array}{l}\text { Participants choose from a } \\
\text { predefined list of values }\end{array}$ & & $\begin{array}{l}\text { Alessa et al. } \\
2008\end{array}$ \\
\hline & & $\begin{array}{l}\text { Participants use dots to mark } \\
\text { locations of values }\end{array}$ & & $\begin{array}{l}\text { Beverly et al. } \\
2008\end{array}$ \\
\hline & & \multirow[t]{3}{*}{$\begin{array}{l}\text { Point density, hotspot, and proximity } \\
\text { analyses }\end{array}$} & & $\begin{array}{l}\text { Brown and } \\
\text { Reed } 2009\end{array}$ \\
\hline & & & & Zhu et al. 2010 \\
\hline & & & & $\begin{array}{l}\text { Sherrouse et } \\
\text { al. } 2011\end{array}$ \\
\hline \multirow[t]{5}{*}{$\begin{array}{l}\text { Place } \\
\text { attachment } \\
\text { mapping }\end{array}$} & $\begin{array}{l}\text { Meanings (including } \\
\text { negative ones) associated } \\
\text { with places participants } \\
\text { marked as important or } \\
\text { special; }\end{array}$ & $\begin{array}{l}\text { In-depth semi-structured/key } \\
\text { informant interviews }\end{array}$ & $\begin{array}{l}\text { Contributory/collaborative - Public } \\
\text { provides data; feedback loops with } \\
\text { managers and the public are built in } \\
\text { at the data analysis phase }\end{array}$ & $\begin{array}{l}\text { Gunderson } \\
\text { and Watson } \\
2007\end{array}$ \\
\hline & $\begin{array}{l}\text { Gunderson and Watson } \\
\text { asked people to map places } \\
\text { they used as well as places } \\
\text { that were important to } \\
\text { them. }\end{array}$ & Purposive or snowball sampling & & $\begin{array}{l}\text { Donovan et al. } \\
2009\end{array}$ \\
\hline & \multirow[t]{3}{*}{$\begin{array}{l}\text { Raymond et al. used a } \\
\text { weighting scheme. }\end{array}$} & $\begin{array}{l}\text { Meaningful places marked with } \\
\text { polygons }\end{array}$ & & $\begin{array}{l}\text { Raymond et al. } \\
2009\end{array}$ \\
\hline & & Thematic analysis of interview data & & Cacciapaglia \\
\hline & & $\begin{array}{l}\text { Hotspot/intensity analysis (sum of } \\
\text { overlapping polygons) }\end{array}$ & & et al. 2012 \\
\hline \multirow[t]{3}{*}{$\begin{array}{l}\text { Wilderness } \\
\text { perceptions } \\
\text { mapping }\end{array}$} & \multirow[t]{3}{*}{$\begin{array}{l}\text { Areas likely to be perceived } \\
\text { as wilderness or wild land } \\
\text { by different types of } \\
\text { recreation users }\end{array}$} & $\begin{array}{l}\text { Surveys of wilderness users to collect } \\
\text { data about physical features } \\
\text { associated with areas that "feel" } \\
\text { like wilderness }\end{array}$ & \multirow[t]{3}{*}{$\begin{array}{l}\text { Contributory - Public provides data; } \\
\text { no mention of feedback loops }\end{array}$} & $\begin{array}{l}\text { Kliskey and } \\
\text { Kearsley } \\
1993\end{array}$ \\
\hline & & \multirow{2}{*}{$\begin{array}{l}\text { Use of geographic overlay } \\
\text { techniques to model a wilderness } \\
\text { continuum on the landscape (i.e. } \\
\text { areas where different categories of } \\
\text { recreation users are likely to feel as } \\
\text { if the area is "wild") }\end{array}$} & & $\begin{array}{l}\text { Carver et al. } \\
2002\end{array}$ \\
\hline & & & & $\begin{array}{l}\text { Flanagan and } \\
\text { Anderson } \\
2008\end{array}$ \\
\hline \multirow[t]{7}{*}{$\begin{array}{l}\text { Collaborative } \\
\text { mapping }\end{array}$} & \multirow{3}{*}{$\begin{array}{l}\text { Conceptualizations of place, } \\
\text { uses of place, priorities for } \\
\text { how different areas of the } \\
\text { landscape should be } \\
\text { managed }\end{array}$} & $\begin{array}{l}\text { Workshop or focus group mapping } \\
\text { sessions; }\end{array}$ & \multirow{3}{*}{$\begin{array}{l}\text { Collaborative-Public provided data } \\
\text { in a context designed to facilitate } \\
\text { discussion over differences in } \\
\text { perceptions of place }\end{array}$} & $\begin{array}{l}\text { Cheng and } \\
\text { Lockwood } \\
2008\end{array}$ \\
\hline & & $\begin{array}{l}\text { Open invitation (agency personnel } \\
\text { and the public); }\end{array}$ & & $\begin{array}{l}\text { Farnum et al. } \\
2008\end{array}$ \\
\hline & & $\begin{array}{l}\text { Identification of landscape units and } \\
\text { development of consensual } \\
\text { composite thematic maps for those } \\
\text { units }\end{array}$ & & \\
\hline & \multirow[t]{4}{*}{$\begin{array}{l}\text { Cultural values (existing and } \\
\text { desired) }\end{array}$} & $\begin{array}{l}\text { Planning effort involved Maori } \\
\text { leaders, elders, and tribal members }\end{array}$ & \multirow{4}{*}{$\begin{array}{l}\text { Co-creation/empowerment-Maori } \\
\text { leaders and tribal members } \\
\text { involved in research design, } \\
\text { implementation, and analysis; } \\
\text { Maori retained control over data }\end{array}$} & $\begin{array}{l}\text { Tipa and } \\
\text { Nelson } 2008\end{array}$ \\
\hline & & $\begin{array}{l}\text { Data collected through focus groups } \\
\text { and semi-structured interviews with }\end{array}$ & & \\
\hline & & key informants; & & \\
\hline & & $\begin{array}{l}\text { Participatory collection of resource } \\
\text { conditions data; }\end{array}$ & & \\
\hline
\end{tabular}


Table 2 (continued)

\begin{tabular}{|c|c|c|c|c|}
\hline $\begin{array}{l}\text { Sense of } \\
\text { place } \\
\text { mapping } \\
\text { category }\end{array}$ & $\begin{array}{l}\text { Sense of place dimensions } \\
\text { mapped }\end{array}$ & Dominant methods & $\begin{array}{l}\text { Participation model (Categories } \\
\text { adapted from Bonney et al. 2009) }\end{array}$ & $\begin{array}{l}\text { Examples } \\
\text { (Chronological } \\
\text { order) }\end{array}$ \\
\hline & & $\begin{array}{l}\text { Focus groups used to analyze data } \\
\text { and develop management priorities }\end{array}$ & & \\
\hline \multirow[t]{4}{*}{ Hybrids } & $\begin{array}{l}\text { Social or cultural values; } \\
\text { landscape services } \\
\text { indicators }\end{array}$ & $\begin{array}{l}\text { Variable approaches have been used, } \\
\text { typically using two or more of the } \\
\text { following methods: } \\
\text { Semi-structured interviews; }\end{array}$ & $\begin{array}{l}\text { Collaborative/contributory-Public } \\
\text { provided data and in all but the } \\
\text { Klain and Chan study also had } \\
\text { input into some aspect of the } \\
\text { research project }\end{array}$ & $\begin{array}{l}\text { McIntyre et al. } \\
2008 \\
\text { Carver et al. } \\
2009\end{array}$ \\
\hline & & Internet or mail surveys; & & $\begin{array}{l}\text { Fagerholm and } \\
\text { Käyhkö } \\
2009\end{array}$ \\
\hline & & Face-to-face surveys; & & $\begin{array}{l}\text { Fagerholm et } \\
\text { al. } 2012\end{array}$ \\
\hline & & $\begin{array}{l}\text { Focus groups to develop values } \\
\text { typology; } \\
\text { Community reflection workshops to } \\
\text { provide input into data analysis and } \\
\text { map interpretation }\end{array}$ & & $\begin{array}{l}\text { Klain and } \\
\text { Chan } 2012^{c}\end{array}$ \\
\hline
\end{tabular}

\footnotetext{
${ }^{\text {a }}$ Tyrväinen et al. had participants assign values to specific green spaces (mapped as polygons) rather than using dots

${ }^{\mathrm{b}}$ Tyrväinen et al. developed thematic maps rather than density analyses

${ }^{\mathrm{c}}$ The Klain and Chan study was the only hybrid study that did not mention a feedback component either to develop the values typology or interpret data
}

determine what physical features different types of people associate with a wilderness experience. Then overlay techniques are applied using appropriate data layers (roads, vegetation, structures, etc.) to produce maps showing areas where the combination of physical characteristics present is likely to produce a sense of being in wilderness for different types of users. "Wilderness" is a term very particular to Anglo settlers in countries such as the US, Canada, Australia, and New Zealand (Guha 1989). Wilderness perceptions mapping is thus unlikely to be very useful in many countries where the concept of wilderness does not exist. Nonetheless, the geographic overlay approach used for mapping wilderness perceptions is potentially useful for mapping other perceptions about place (e.g., areas where different types of people feel unsafe). The role of participants in wilderness perceptions mapping is typically limited to providing data.

Collaborative Mapping This fourth strand considers SOP mapping an important tool for process reasons as well as for the data it produces. Examples of this type of mapping are rare, but they are sufficiently different from other SOP mapping approaches that they are worth a brief mention. Rather than aggregating individual maps into composite maps, collaborative mapping brings together agency representatives and stakeholders or the broader public to develop consensual maps that capture cultural values (Tipa and
Nelson 2008) or conceptualizations of place and ideas on how areas should be managed (Cheng and Lockwood 2008; Farnum et al. 2008).

\section{Applications of SOP Mapping}

Values mapping studies have informed forest planning in Alaska (Brown et al. 2002) and Canada (Beverly et al. 2008), natural area planning in Australia (Zhu et al. 2010), and urban green space planning in Finland (Tyrväinen et al. 2007). Place attachment mapping studies have provided input for forest fire management in Montana (Cacciapaglia et al. 2012) and biodiversity conservation area prioritization in eastern Washington (Donovan et al. 2009). Wilderness perceptions mapping has been used for wild lands management in New Zealand (Kliskey and Kearsley 1993), Britain (Carver et al. 2002), and the western United States (Flanagan and Anderson 2008). Researchers in New Zealand have used collaborative sense of place mapping to fulfill a legal mandate to recognize Maori cultural interests in watershed management (Tipa and Nelson 2008). The U.S. Forest Service has coordinated collaborative sense of place mapping to inform national forest planning (Cheng and Lockwood 2008; Farnum et al. 2008; Hall et al. 2009b). Hybrid approaches combining values mapping, place attachment mapping, and collaborative mapping have been 
used to provide data for land use planning on Zanzibar (Fagerholm et al. 2012), coastal management (Klain and Chan 2012) and recreation management in Canada (McIntyre et al. 2008), and fire management in Montana (Carver et al. 2009).

\section{Challenges Associated with SOP Mapping}

A major challenge of SOP mapping is that most projects rely on mappers' memories or mental images of places and rarely include a field-based ground-truthing component. SOP mapping is thus highly susceptible to locational errors and ambiguities in spatial representations (Zhu et al. 2010). This susceptibility is magnified for mapping projects in which participants mark locations using sticker dots, as there is no way to know the spatial extent that each dot represents. Brown and Pullar (2012) found that it took ten times as many point-based maps as polygon-based maps to achieve similar patterns when analyzing the data. They recommend that the sticker dot method be used for mail and internet surveys which can reach a large number of people and polygon methods for face-to-face interviews.

SOP mapping projects struggle with the question of whose landscape values or place meanings should be mapped. Many projects have solicited input only from individuals residing in or near the study site or visiting the area (Brown and Reed 2009; Donovan et al. 2009; Tyrväinen et al. 2007). Yet many planning decisions need to account for the values and place meanings of non-residents including those who never visit the area. In industrialized countries, ready access to internet technologies has made it feasible to collect SOP data relatively inexpensively from non-residents but techniques for doing so remain experimental (Carver et al. 2002). However, well-educated, wealthier men tend to be disproportionately likely to participate in mail and internet surveys and other methods, such as workshops targeting specific subgroups, may be needed to encourage broader-based participation (Biedenweg et al. in review).

Brown and Reed (2009) describe chronic difficulties with persuading natural resource planners to integrate landscape values mapping data into formal planning. They attribute this resistance to the lack of agency directives to include landscape value data in forest planning, the costs of collecting and analyzing data, and the lack of agency social science expertise. However, researchers who built community and planner feedback loops into their projects report positive responses from planners (Donovan et al. 2009; Raymond et al. 2009; Tipa and Nelson 2008). This suggests that more collaborative forms of SOP mapping may help overcome skepticism within government agencies about the value of such data.

\section{Discussion}

Each of the approaches examined in this review provides a unique but important perspective on human-environmental interactions. Table 1 summarizes how TRU, LEK, and SOP mapping compare with respect to their theoretical roots, underlying models of participation, major applications, dominant data collection methods, and implementation challenges. Both TRU and LEK mapping emerged from efforts by indigenous and local communities to gain greater influence or control over land and resources and are theoretically and methodologically informed by the subfields of cultural ecology, political ecology, and international development in the disciplines of cultural geography and anthropology. TRU and LEK mapping draw heavily from the ethnographer's toolkit to translate individual and collective cognitive maps into "standard" maps adhering to western cartographic conventions. Both approaches emphasize the use of qualitative methods combined with field-based or remotely sensed measurements of boundaries, culturally important locations, or resource conditions. Additionally, many TRU and LEK mapping projects are driven by an empowerment model that seeks to maximize participants' control over the mapping process - and increasingly over the data and maps produced through those processes.

In contrast, SOP mapping is informed theoretically and methodologically by the disciplines of behavioral geography, environmental psychology, and environmental planning. Aside from the difference in thematic focus, SOP mapping differs significantly from LEK and TRU mapping in two respects. First, most SOP mapping projects conceptualize participants as providers of data, or at most incorporate feedback loops during the data analysis stage. Although collaborative forms of SOP mapping do exist, they are rare. The discussions in LEK and TRU mapping projects concerning data sharing and control agreements and steps taken to involve community members in all research phases are strikingly absent in most SOP mapping studies. Tipa and Nelson's (2008) collaborative mapping with the Maori is a notable exception and indicates that more collaborative approaches to SOP mapping are possible. A second key distinction between SOP mapping and TRU/LEK mapping is the absence of efforts in SOP mapping projects to ground-truth locations of the places or values mapped. This difference partly reflects differences in the nature of the data and mapping goals, with sense of place locations being more abstract and harder to pin down compared to land boundaries or wildlife harvesting sites. However, it may also reflect the disciplinary "homes" of these approaches, with field-based observations being a crucial component of ethnographers' toolkits but less commonly used by cognitive psychologists and behavioral geographers. 
Despite the differences in the three mapping approaches, they share a number of issues that need to be addressed in human ecology mapping projects. Three of these crosscutting issues are briefly discussed below.

Limitations of GIS-Based Maps as Tools for Representing Socioecological Systems All three approaches share the aim of translating individual or collective mental maps into Cartesian coordinate systems. Yet mental map boundaries are often dynamic and fuzzy, qualities that do not translate well into standard maps (McCall and Dunn 2012). Translation of mental maps into GIS data layers runs the risk of reifying boundaries as solid and rigid lines, rather than depicting them as the porous and shifting membranes they often resemble. Moreover, mental maps consist of far more than spatial locations: they include social relations, histories, events, and memories associated with those locations. This data, too, is challenging to translate into standard maps or geodatabases and, as a result, human ecology mapping inevitably oversimplifies and renders invisible important aspects of human connections to landscapes.

Building in mechanisms to capture the fuzziness of boundaries in mental maps can help limit some risks associated with HEM projects. For example, TRU mapping projects can incorporate mechanisms for identifying and documenting overlapping and secondary rights to land and resources (Bryan 2011), providing communities and individuals the flexibility in tenure arrangements needed to adapt to changing social and ecological conditions. Carver et al. (2009) have experimented with having participants in web-based sense of place mapping use a customized "spray can" tool to represent the fuzziness of spatial locations. Incorporation into geodatabases of explanatory narratives, oral histories, or land management histories associated with spatial locations can help human ecology mapping projects retain important contextual data. However, researchers continue to struggle with ways to analyze and display qualitative data. Interactive multi-media web-based cyber atlases, such as the Inuit sea ice atlas (Pulsifer et al. 2011), have strong potential as platforms for representing the multiple facets of human-environmental interactions in accessible formats but they require considerable expertise and funding to develop.

Power Differentials Mapping projects are an arena where power and access to resources are negotiated by the parties at the table (Harley 1988), and those who are not engaged in mapping may not be heard. A related issue is that spatial acuity and map interpretation skills needed to participate effectively in mapping are often unequally distributed within communities or across stakeholder groups. For example, if data is gathered or shared through a web-based interactive GIS application, people comfortable with or with easy access to such technologies may be more likely to participate than those who are not (Eisner et al. 2012). TRU and LEK mapping practitioners have sought to minimize risks linked to power and capacity imbalances by following participatory GIS "good governance" guidelines (McCall and Dunn 2012), including recognition of intellectual property rights, sensitivity to local perceptions of space, awareness of power differentials within and between communities, creation of opportunities for local input and decision-making, and training community members in mapping and analysis. These principles could potentially be applied to SOP mapping projects as well.

Power imbalances could also be addressed by recruiting and training socially marginalized or less powerful community members in mapping techniques (Sletto 2009), through the use of geotechnologies likely to be understood by nonliterate community members (such as photomaps rather than topographical maps) (Mather 2000), or organizing mapping sessions geared to specific audiences (Biedenweg et al. in review). In Canada, many First Nations have developed capacity to do their own GIS-based mapping and have created networks, such as the Aboriginal Mapping Network, to assist other groups in developing similar capacities (Brown and Nicholas 2012). As technology for recording spatial locations becomes more widely available, opportunities for removing barriers to participation in mapping processes will increase (McCall and Dunn 2012). The use of a variety of mapping approaches and tools tailored to different skill and comfort levels can also help ensure that a broad spectrum of community members or stakeholders are included in mapping projects.

Resistance by Resource Managers to the use of Human Ecology Mapping Data Perhaps the biggest challenge facing efforts to integrate human ecology mapping into GIS-based environmental planning is resistance on the part of scientists, resource managers, and planners. The reasons for resistance are many. TRU mapping may threaten forest agencies' longstanding control over valuable resources and forest agents may be skeptical of local communities' capacity to manage forests sustainably (Roth 2004), sometimes justifiably so. Managers and planners, most of whom are trained in the natural sciences and have little knowledge of social science methods, are skeptical of the validity of LEK or confused about what it is (Brook and McLachlan 2008; Kendrick and Manseau 2008). Additionally, collecting and validating LEK can be costly (Kendrick and Manseau 2008). Data collection costs and lack of agency directives requiring the use of sense of place data also hinder efforts to integrate SOP mapping into resource planning (Brown and Reed 2009). The establishment of relationships of trust and respect between community members, managers, and scientists is a key factor in successful efforts to integrate human ecology mapping into environmental management (Roth 2004; 
Thornton and Scheer 2012; Tipa and Nelson 2008). Projects that emphasize community participation in all phases of mapping tend to be more effective at creating such relationships than those in which community members' role is limited to providing data (Brook and McLachlan 2008; Herlihy 2003; Thornton and Scheer 2012). Incorporating testing of LEK into management programs can also help address concerns about its validity (Gilchrist et al. 2005). The integration of social science coursework into university level natural resource and ecological programs is a crucial step toward breaking down resistance to the use of human ecology mapping in environmental planning (Brook and McLachlan 2008).

\section{Conclusion}

Each of the approaches described in this review adds to our knowledge of a particular dimension of human-environmental interactions. Used in combination, they offer the potential to produce the kinds of multi-scalar and multi-dimensional knowledge needed to manage complex ecosystems. To maximize the effectiveness of human ecology mapping, however, two key constraints need to be overcome. One is the challenge of storing, accessing, analyzing and representing nonquantitative and non-cartographic data in GIS-based environments. Fortunately, the past decade has seen significant development of qualitative GIS approaches that link images, annotated sketch maps, and narratives with spatial data. As these methods are refined and applied to real-world planning situations, incorporating qualitative data into human ecology mapping will become easier. A second, much more challenging constraint is the lack of social science expertise in most natural resource agencies. Overcoming this constraint requires a reconceptualization of the fundamental job of such agencies and the areas of expertise that need to be represented on their staffs. These agencies have long viewed measuring and mapping natural resources (e.g., trees, fish, soil) as a critical aspect of what they do. If they are to be effective managers of socioecological systems, measuring and mapping human uses and values also must become part of their task as well.

Acknowledgments This work was supported by the USDA-Forest Service, PNW Research Station under Joint Venture Agreement PNW 08-JV-11261985-177, Mapping socioecological meanings of Olympic Peninsula landscapes. We thank the two anonymous reviewers for their feedback on the article and Leilan Greer for her assistance with copy-editing.

\section{References}

Agrawal, A. (1995). Dismantling the Divide between Indigenous and Scientific Knowledge. Development and Change 26: 413-439.
Alessa, N., Kliskey, A., and Brown, G. (2008). Social-ecological Hotspots Mapping: A Spatial Approach for Identifying Coupled Socialecological Space. Landscape and Urban Planning 85(1): 27-39.

Aporta, C. (2011). Shifting Perspectives on Shifting Ice: Documenting and Representing Inuit Use of the Sea Ice. The Canadian Geographer 55(1): 6-19.

Aswani, S., and Lauer, M. (2006). Incorporating Fishermen's Local Knowledge and Behavior into Geographical Information Systems (GIS) for Designing Marine Protected Areas in Oceania. Human Organization 65(1): 81-102.

Barnaud, C., van Paassen, A., Trébuil, G., Promburom, T., and Bousquet, F. (2010). Dealing with Power Games in a Companion Modeling Process: Lessons from Community Water Management in Thailand Highlands. The Journal of Agricultural Education and Extension 16(1): 55-74.

Barodien, B., and Barry, M. (2004). Palm Computers for Spatially Referenced Social Surveys in Upgrading Informal Settlements. New Zealand Surveyor 294(June): 3-9.

Bauer, K. (2009). On the Politics and the Possibilities of Participatory Mapping and GIS: Using Spatial Technologies to Study Common Property and Land Use Change among Pastoralists in Central Tibet. Cultural Geographies 16(2): 229-252.

Berkes, F., Colding, J., and Folke, C. (2000). Rediscovery of Traditional Ecological Knowledge as Adaptive Management. Ecological Applications 10(5): 1251-1262.

Bethel, M. B., Brien, L. F., Danielson, E. J., Laska, S. B., Troutman, J. P., Boshart, W. M., Giardano, M. J., and Phillips, M. A. (2011). Blending Geospatial Technology and Traditional Ecological Knowledge to Enhance Restoration Decision-support Processes in Coastal Louisiana. Journal of Coastal Research 27(3): 555-571.

Beverly, J. L., Uto, K., Wilkes, J., and Bothwell, P. (2008). Assessing Spatial Attributes of Forest Landscape Values: An Internet-based Participatory Mapping Approach. Canadian Journal of Forest Research 38(2): 289-303.

Bonney, R., Ballard H., Jordan R., McCallie E., Phillips T., Shirk J., and Wilderman C. C. (2009). Public Participation in Scientific Research: Defining the Field and Assessing Its Potential for Informal Science Education. A CAISE Inquiry Group Report. Center for Advancement of Informal Science Education, Washington D.C.

Brody, H. (1982). Maps and Dreams. Pantheon Books, New York.

Brook, R. K., and McLachlan, S. M. (2008). Trends and Prospects for Local Knowledge in Ecological and Conservation Research and Monitoring. Biodiversity and Conservation 17: 3501-3512.

Brown, D., and Nicholas, G. (2012). Protecting Indigenous Cultural Property in the Age of Digital Democracy: Institutional and Communal Responses to Canadian First Nations and Maori Heritage Concerns. Journal of Material Culture 17(3): 307324.

Brown, G., and Pullar, D. V. (2012). An Evaluation of the Use of Points versus Polygons in Public Participation Geographic Information Systems Using Quasi-experimental Design and Monte Carlo Simulation. International Journal of Geographical Information Science 26(2): 231-246.

Brown, G. G., and Reed, P. (2009). Public Participation GIS: A New Method for Use in National Forest Planning. Forest Science 55 (2): 166-182.

Brown, G. G., Reed, P., and Harris, C. C. (2002). Testing a Place-based Theory for Environmental Evaluation: An Alaska Case Study. Applied Geography 22: 49-76.

Bryan, J. (2011). Walking the Line: Participatory Mapping, Indigenous Rights, and Neoliberalism. Geoforum 42: 40-50.

Cacciapaglia, M. A., Yung, L., and Patterson, M. E. (2012). Place Mapping and the Role of Spatial Scale in Understanding Landowner Values of Fire and Fuels Management. Society and Natural Resources 25(5): 453-467. 
Carver, S., Evans, A., and Fritz, S. (2002). Wilderness Attribute Mapping in the United Kingdom. International Journal of Wilderness 8(1): 24-29.

Carver, S., Watson, A., Waters, T., Matt, R., Gunderson, K., and Davis, B. (2009). Developing computer-based participatory approaches to mapping landscape values for landscape and resource management. In Geertman, S., and Stillwell, J. (eds.), Planning Support Systems Best Practice and New Methods. Springer, Dordrecht, pp. 431-448.

Chalmers N., and Fabricius C. (2007). Expert and Generalist Local Knowledge about Land-cover Change on South Africa's Wild Coast: Can Local Ecological Knowledge Add Value to Science? Ecology and Society 12(1): 10 [online], http://www.ecologyandsociety. org/vol12/iss1/art10/.

Chapin, M., Lamb, Z., and Threlkeld, B. (2005). Mapping Indigenous Lands. Annual Review of Anthropology 34: 619-638.

Charnley, S., Fischer, P., and Jones, E.T. (2008). Traditional and Local Ecological Knowledge about Forest Biodiversity in the Pacific Northwest. General Technical Report PNW-GTR-751. U.S. Department of Agriculture, Forest Service, Portland, OR.

Cheng, A. S., Kruger, L. E., and Daniels, S. E. (2003). "Place" as an Integrating Concept in Natural Resource Politics: Propositions for a Social Science Research Agenda. Society and Natural Resources 16: 87-104.

Cheng A.S., and Lockwood C. (2008). The Grand Mesa, Uncompaghre, and Gunnison National Forests. In Farnum, J., and Kruger, L. (eds.), Place-based Planning: Innovations and Applications from Four Western Forests. General Technical Report PNW-GTR-741. U.S. Department of Agriculture, Forest Service, Portland, OR, pp. 33-40.

Cronkleton, P., Albornoz, M. A., Barnes, G., Evans, K., and de Jong, W. (2010). Social Geomatics: Participatory Forest Mapping to Mediate Resource Conflict in the Bolivian Amazon. Human Ecology 38: 65-76.

de Freitas, D., and Tagliani, P. (2009). The Use of GIS for Integration of Traditional and Scientific Knowledge in Supporting Artisanal Fisheries Management in Southern Brazil. Journal of Environmental Management 90: 2071-2080.

Donovan, S. M., Looney, C., Hanson, T., Sánchez de León, Y., Wulfhorst, J., Eigenbrode, S. D., Jennings, M., JohnsonMaynard, J., and Bosque Pérez, N. A. (2009). Reconciling Social and Biological Needs in an Endangered Ecosystem: The Palouse as a Model for Bioregional Planning. Ecology and Society 14(1): 9. http://www.ecologyandsociety.org/vol14/ iss $1 /$ art9.

Eisner, W. R., Cuomo, C. J., Hinkel, K. M., Jelacic, J., Kim, C., and del Alba, D. (2012). Producing an Indigenous Knowledge Web GIS for Arctic Alaska Communities: Challenges, Successes, and Lessons Learned. Transactions in GIS 16(1): 17-37.

Endter-Wada, J., Blahna, D., Krannich, R., and Brunson, M. (1998). A Framework for Understanding Social Science Contributions to Ecosystem Management. Ecological Applications 8(3): 891-904.

Endter-Wada, J., and Blahna, D. J. (2011). Linkages to Public Land Framework: Toward Embedding Humans in Ecosystem Analysis by Using 'Inside-out Social Assessment. Ecological Applications 21(8): 3254-3271.

Fagerholm, N., and Käyhkö, N. (2009). Participatory Mapping and Geographical Patterns of the Social Landscape Values of Rural Communities in Zanzibar, Tanzania. Fennia 187: 43-60.

Fagerholm, N., Käyhkö, N., Ndumbaro, F., and Khamis, M. (2012). Community Stakeholders' Knowledge in Landscape Assessments: Mapping Indicators for Landscape Services. Ecological Indicators 18: 421-433.

Farnum, J., and Kruger, L. (2008). Place-based Planning: Innovations and Applications from Four Western Forests. General Technical Report PNW-GTR-741. U.S.Department of Agriculture, Forest Service, Portland, OR

Farnum, J. O., DeZort, A., and Bean-Dochnal, J. (2008). The Beaverhead-Deerlodge National Forest. In Farnum, J., and
Kruger, L. (eds.), Place-based Planning: Innovations and Applications from Four Western Forests. General Technical Report PNW-GTR-741. U.S. Department of Agriculture, Forest Service, Portland, OR, pp. 7-14.

Feinberg, R., Dymon, U. J., Paiaki, P., Rangituteki, P., Nukuriaki, P., and Rollins, M. (2003). 'Drawing the Coral Heads': Mental Mapping and its Physical Representation in a Polynesian Community. The Cartographic Journal 40(3): 243-253.

Flanagan, T. S., and Anderson, S. (2008). Mapping Perceived Wilderness to Support Protected Areas Management in the San Juan National Forest, Colorado. Forest Ecology and Management 256: $1039-1048$.

Fox, J. (2002). Siam Mapped and Mapping in Cambodia: Boundaries, Sovereignty, and Indigenous Conceptions of Space. Society and Natural Resources 15(1): 65-78.

Freeman M. M. R. (1992). The Nature and Utility of Traditional Ecological Knowledge. Canadian Arctic Resources Committee 10(1). [online], http://www.carc.org/pubs/v20no1/utility.htm.

Gearheard, S., Aporta, C., Aipellee, G., and O'Keefe, K. (2011). The Igliniit Project: Inuit Hunters Document Life on the Trail to Map and Monitor Arctic Change. The Canadian Geographer 55(1): 42-55.

Gilchrist, G., Mallory, M., and Merkel, F. (2005). Can Local Ecological Knowledge Contribute to Wildlife Management? Case Studies of Migratory Birds. Ecology and Society 10(1): 20. http://www.ecologyandsociety.org/vol10/iss1/art20/.

Gould, P. R. (1970). On mental maps. In English, P. W., and Mayfield, R. C. (eds.), Man, Space, and Environment: Concepts in Contemporary Human Geography. Oxford University Press, New York, pp. 260-282.

Guha, R. (1989). Radical American Environmentalism and Wilderness Preservation: A Third World Critique. Environmental Ethics 11: 71-83.

Gunderson, K., and Watson, A. (2007). Understanding Place Meanings on the Bitterroot National Forest, Montana. Society and Natural Resources 20(8): 705-721.

Hall, G. B., Moore, A., Knight, P., and Hanley, N. (2009a). The Extraction and Utilization of Local and Scientific Geospatial Knowledge within the Bluff Oyster Fishery, New Zealand. Journal of Environmental Management 90: 2055-2070.

Hall T. E., Farnum J. O., Slider T. C., and Ludlow K. (2009). New Approaches to Forest Planning: Inventorying and Mapping Place Values in the Pacific Northwest Region. Research Note PNW-RN562. U.S. Department of Agriculture, Forest Service, Portland, OR.

Harley, J. B. (1988). Maps, knowledge, and power. In Cosgrove, D., and Daniels, S. (eds.), The Iconography of Landscape: Essays on the Symbolic Representation, Design and Use of Past Environments. Cambridge University Press, Cambridge, pp. 277-312.

Herlihy, P. H. (2003). Participatory Research Mapping of Indigenous Lands in Darién, Panama. Human Organization 62(4): 315-331.

Hodgson, D. L., and Schroeder, R. A. (2002). Dilemmas of Countermapping Community Resources in Tanzania. Development and Change 33: 79-100.

Houde, N. (2007). The Six Faces of Traditional Ecological Knowledge: Challenges and Opportunities for Canadian Co-management Arrangements. Ecology and Society 12(2): 34. http://www. ecologyandsociety.org/vol12/iss2/art34/.

Ishikawa, T., and Montello, D. R. (2006). Spatial Knowledge Acquisition from Direct Experience in the Environment: Individual Differences in the Development of Metric Knowledge and the Integration of Separately Learned Places. Cognitive Psychology 52: 93-129.

Kendrick, A., and Manseau, M. (2008). Representing Traditional Knowledge: Resource Management and Inuit Knowledge of Barren-Ground Caribou. Society and Natural Resources 21: 404-418.

Klain, S. C., and Chan, K. M. A. (2012). Navigating Coastal Values: Participatory Mapping of Ecosystem Services for Spatial Planning. Ecological Economics 82: 104-113. 
Kliskey, A. D., and Kearsley, G. W. (1993). Mapping Multiple Perceptions of Wilderness in Southern New Zealand. Applied Geography 13: 203-223.

Kyem, P. A. K. (2004). Of Intractable Conflicts and Participatory GIS Applications: The Search for Consensus Amidst Competing Claims and Institutional Demands. Annals of the Association of American Geographers 94(1): 37-57.

Lewis, J. (2012). Technological Leap-frogging in the Congo Basin, Pygmies and Global Positioning Systems in Central Africa: What has Happened and Where is it Going? African Study Monographs Supplement 43(March): 15-44.

Liu, J., Dietz, T., Carpenter, S. R., Alberti, M., Folke, C., Moran, E., Pell, A. N., Deadman, P., Kratz, T., Lubchenco, J., Ostrom, E., Ouyang, Z., Provencher, W., Redman, C. L., Schneider, S. H., and Taylor, W. W. (2007). Complexity of Coupled Human and Natural Systems. Science 317(5844): 1513-1516.

Lynch, K. (1960). The Image of the City. Harvard-MIT Joint Center for Urban Studies, Boston.

Marten, G. (2001). Human Ecology-Basic Concepts for Sustainable Development. Earthscan, New York.

Mather, R. A. (2000). Using Photomaps to Support Participatory Processes of Community Forestry in the Middle Hills of Nepal. Mountain Research and Development 20(2): 154-161.

McCall, M. K., and Dunn, C. E. (2012). Geo-information Tools for Participatory Spatial Planning: Fulfilling the Criteria for 'Good' Governance? Geoforum 43: 81-94.

McCall, M. K., and Minang, P. A. (2005). Assessing Participatory GIS for Community-based Natural Resource Management: Claiming Community Forests in Cameroon. The Geographical Journal 171 (4): 340-356.

McCarthy, D., Whitelaw, D. P., Anderson, G. S., Cowan, D., McGarry, F., Robins, A., Gardner, H. L., Barbeau, C. D., Charania, N. D., General, Z., Liedtke, J., Sutherland, C., Alencar, P., and Tsuji, L. J. S. ( 2012). Collaborative Geomatics and the Mushkegowuk Cree First Nations: Fostering Adaptive Capacity for Community-Based Sub-arctic Natural Resource Management. Geoforum 43: 305-314.

McIntyre, N., Moore, J., and Yuan, M. (2008). A Place-based, Valuescentered Approach to Managing Recreation on Canadian Crown Lands. Society and Natural Resources 21(8): 657-670.

McKenna, J., Quinn, R. J., Donnelly, D. J., and Cooper, J. A. G. (2008). Accurate Mental Maps as an Aspect of Local Ecological Knowledge (LEK): A Case Study from Lough Neagh, Northern Ireland. Ecology and Society 13(1): 13. http://www.ecologyandsociety.org/ vol13/iss 1/art13/.

Murray, G., Neis, B., Palmer, C. T., and Schneider, D. C. (2008). Mapping Cod: Fisheries Science, Fish Harvesters' Ecological Knowledge and Cod Migrations in the Northern Gulf of St. Lawrence. Human Ecology 36(4): 581-598.

Palmer, C. T., and Wadley, R. L. (2007). Local Environmental Knowledge, Talk, and Skepticism: Using 'LES' to Distinguish 'LEK' from 'LET' in Newfoundland. Human Ecology 35(6): 749-760.

Peluso, N. L. (1995). Whose Woods Are These? Counter-mapping Forest Territories in Kalimantan, Indonesia. Antipode 27(4): 383-406.

Perkins, C. (2003). Cartography: Mapping Theory. Progress in Human Geography 27(3): 341-351.

Proshansky, H. M., Fabian, A. K., and Kaminoff, R. (1983). Placeidentity: Physical World Socialization of the Self. Journal of Environmental Psychology 3: 57-83.
Pulsifer, P. L., Laidler, G. J., Taylor, D. R. F., and Hayes, A. (2011). Towards an Indigenist Data Management Program: Reflections on Experiences Developing An Atlas of Sea Ice Knowledge and Use. The Canadian Geographer 55(1): 108-124.

Raymond, C. M., Bryan, B. A., MacDonald, D. H., Cast, A., Strathearn, S., Grandgirard, A., and Kalivas, T. (2009). Mapping Community Values for Natural Capital and Ecosystem Services. Ecological Economics 68: 1301-1315.

Roth, R. (2004). Spatial Organization of Environmental Knowledge: Conservation Conflicts in the Inhabited Forest of Northern Thailand. Ecology and Society 9(3): 5. http://www.ecologyandsociety. org/vol9/iss3/art5/.

Rundstrom, R. A. (1990). A Cultural Interpretation of Inuit Map Accuracy. Geographical Review 80(2): 155-168.

Sherrouse, B. C., Clement, J. M., and Semmens, D. J. (2011). A GIS Application for Assessing, Mapping, and Quantifying the Social Values of Ecosystem Services. Applied Geography 31: 748-760.

Sletto, B. I. (2009). "We Drew What We Imagined": Participatory Mapping, Performance, and the Arts of Landscape Making. Current Anthropology 50(4): 443-476.

Smith, D. A., Herlihy, P. H., Viera, A. R., Kelly, J. H., Hilburn, A. M., Robledo, M. A., and Dobson, J. E. (2012). Using Participatory Research Mapping and GIS to Explore Local Geographic Knowledge of Indigenous Landscapes in Mexico. Focus on Geography 55(4): 119-124.

Soini, K. (2001). Exploring Human Dimensions of Multifunctional Landscapes through Mapping and Map-making. Landscape and Urban Planning 57: 225-239.

Stedman, R. C. (2003). Is It Really A Social Construction?: The Contribution of the Physical Environment to Sense of Place. Society and Natural Resources 16: 671-685.

Steiner, F. (2002). Human Ecology. Island Press, Washington, D.C.

St Martin, K., and Hall-Arber, M. (2008). The Missing Layer: Geotechnologies, Communities, and Implications for Marine Spatial Planning. Marine Policy 32(5): 779-786.

Thornton, T. F., and Scheer, A. M. (2012). Collaborative Engagement of Local and Traditional Knowledge and Science in Marine Environments: A Review. Ecology and Society 17(3): 8. http:// dx.doi.org/10.5751/ES-04714-170308.

Tipa, G., and Nelson, K. (2008). Introducing Cultural Opportunities: A Framework for Incorporating Cultural Perspectives in Contemporary Resource Management. Journal of Environmental Policy and Planning 10(4): 313-337.

Tobias, T. N. (2000). Chief Kerry's Moose: A Guidebook to Land Use and Occupancy Mapping, Research Design and Data Collection. Ecotrust Canada and Union of BC Indian Chiefs, Vancouver.

Tuan, Y. F. (1977). Space and Place: The Perspective of Experience. Edward Arnold Ltd, London.

Tyrväinen, L., Mäkinen, K., and Schipperijn, J. (2007). Tools for Mapping Social Values of Urban Woodlands and Other Green Areas. Landscape and Urban Planning 79(1): 5-19.

Vermeylen, S., and Davies, G. (2012). Deconstructing the Conservancy Map: Hxaro, N!ore, and Rhizomes in the Kalahari. Cartographica 47(2): 121-134.

Williams, D. R., and Stewart, S. I. (1998). Sense of Place: An Elusive Concept that is Finding a Home in Ecosystem Management. Journal of Forestry 96: 18-23.

Zhu, X., Pfueller, S., Whitelaw, P., and Winter, C. (2010). Spatial Differentiation of Landscape Values in the Murray River Region of Victoria, Australia. Environmental Management 45(5): 896-911. 